\title{
Cavitation erosion resistance of the chosen aluminum alloys
}

Robert Jasionowski, PhD. Eng. ${ }^{1}$, Marzena Podrez-Radziszewska, PhD. Eng. ${ }^{2}$, Dariusz Zasada, PhD. Eng. ${ }^{3}$

${ }^{1}$ Institute of Basic Technical Sciences, Maritime University of Szczecin, Wały Chrobrego 1-2, 70-500 Szczecin, Poland, r.jasionowski@am.szczecin.pl

${ }^{2}$ Insitute of Materiale Science and Applied Mechanics, Wroclaw University of Technology, Smoluchowskiego 25, 50-372 Wrocław, Poland

${ }^{3}$ Department of Metallurgy and Material Technology, Military University of Technology, Kaliskiego 2, 00-908 Warszawa, Poland

The cavitation erosion is a process of material deterioration as a result of materialization, increase and decrease of the cavitation bubbles in different types of liquid. The cavitation erosion materials are used to prevent the devastating effect of imploding bubbles. The aluminum alloys are often used on the parts of machines exposed to cavitation erosion phenomenon. The following article brings up the study of the results of investigation cavitation erosion resistance aluminum alloys: EN AW-2017A, EN AW-5754 and EN AW-7075.

Keywords: cavitation, cavitation erosion, aluminium alloys.

\section{Acknowledgements}

Scientific work funded by the Ministry of Education and Science in the years $2011 \div 2014$ as a research project No. N N507231040.

\section{References}

[1] VARGEL C. (2004). Corrosion of aluminium, Publishing Editor Elsevier Ltd, Oxford.

[2] CHAWLA S.L., GUPTA R.K. (1993). Materials Selection for Corrosion Control, ASM International, USA.

[3] EARLAND S., NASH D., GARDEN B. (2003). Guide to European Pressure Equipment, Professional Engineering Publishing, London.

[4] KWIATKOWSKI L. (2009). Podatność na korozję i skuteczność aktualnych metod ochrony przed korozją stopów aluminium stosowanych w budownictwie, Inżynieria Powierzchni, No. 4/2009, pp. 24-33.

[5] BUJNIEWICZ Z., CUDNY K., WILCZA M. (1971). Stopy aluminium w budownictwie okrętowym, Wydawnictwo Morskie, Gdańsk.

[6] JASIONOWSKI R. (2003). Badania odporności materiałów na erozję kawitacyjną. Cz. I. Urządzenia. Zeszyty Naukowe WSM, No. 72, pp. 105-120.

[7] JASIONOWSKI R., ZASADA D., CHMIELEWSKI M. (2009). Odporność na erozję kawitacyjną stopu aluminium EN AW-6063 poddanego obróbce plastycznej na zimno. XXXVII Szkoła Inżynierii Materiałowej, pp. 424-428. 